九州大学学術情報リポジトリ

Kyushu University Institutional Repository

\title{
Assessment of Cell Membrane Thermostability and Silicon Supplement on Dendrobium Lucky Girl
}

Wu, Shing-Kuan

Department of Horticulture, National Chung Hsing University Institute of Tropical Agriculture, Kyushu University

Miyajima, Ikuo

Institute of Tropical Agriculture, Kyushu University

Huang, Kuang-Liang

Department of Horticultural Science, National ChiayiUniversity | Institute of Tropical Agriculture, Kyushu University

Kuo, Ya-Chin

Department of Horticulture, National Chung Hsing University | Institute of Tropical Agriculture, Kyushu University

他

https://doi.org/10.5109/1833814

出版情報：九州大学大学院農学研究院紀要. 62 (2)，pp.337-343，2017-09-08. Faculty of Agriculture, Kyushu University

バージョン :

権利関係 : 


\title{
Assessment of Cell Membrane Thermostability and Silicon Supplement on Dendrobium Lucky Girl
}

\author{
Shing-Kuan WU' ${ }^{1}$, Ikuo MIYAJIMA ${ }^{2}$, Kuang-Liang HUANG ${ }^{3}$, \\ Ya-Chin KUO ${ }^{1}$ and Ruey-Song $\mathrm{LIN}^{1 *}$
}

\author{
Institute of Tropical Agriculture, Kyushu University, \\ Fukuoka 812-8581, Japan \\ (Received April 25, 2017 and accepted May 10, 2017)
}

\begin{abstract}
Dedrobium Lucky Girl leaves position presented different cell membrane thermostability, respectively. It has enhancing the relative injury value when temperature exceeded $50^{\circ} \mathrm{C}$. In terms of silicon dioxide treatments decreased leaves ion leakage, malondialdehyde content, and existed higher chlorophyll content which evaluated by water bath temperature at $50^{\circ} \mathrm{C}$. Result not only presented higher root activity and chlorophyll SPAD value at $150 \mathrm{mg} \cdot \mathrm{L}^{-1}$ silicon dioxide treatment, but also showed more leaves at 300-600 $\mathrm{mg} \cdot \mathrm{L}^{-1}$ silicon dioxide treatments during vegetative stage. Even though, silicon dioxide treatments had no significant difference among some horticultural characteristic, however it decreased flower bud abortion rate at $150 \mathrm{mg} \cdot \mathrm{L}^{-1}$ treatment.
\end{abstract}

Key words: cell membrane thermostability, heat-tolerance, ion leakage, Nobile Dendrobium, silicon dioxide

\section{INTRODUCTION}

Temperature is an important factor for growth and development of plant, high temperature cause morphoanatomical, physiological and biochemical changes of plant during the growing season (Wahid et al., 2007). The mesophyll cell of thermo-sensitive cultivar cabbage (Brassica oleracea var. capitata L.) showed significant ultrastructural change than thermo-resistant cultivar, such as chloroplasts membrane rupture, structural alteration of thylakoid membrane and disruption of nuclear envelope (Miao et al., 1994). High temperature lead to roll up of leaves in Chinese cabbage (Brassica campestris ssp. L. pekinensis) (Wu et al., 1995). The photosynthesis or photosynthetic rate was inhibited by high temperature in common bean and salvia taxa (Chaisompongpan et al., 1990; Lasseigne et al., 2007). Even Liu and Huang (2000a) reported that carbohydrate availability was associated with heat stress in creeping bentgrass. Moreover, high temperature stress also caused to affect chlorophyll content, chlorophyll fluorescence parameter and antioxidant systems in early cauliflower (Wang et al., 2004).

Silicon is not an essential element on plant growth and development. It has absorbed, translocated and accumulated of plant by silicic acid and silica gel form (Epstein, 1999; Yoshida, 1975). In fact, silicon has accelerated growth, development and enhanced stresses tolerance of plant, such as inhibited serious extra transpiration and increased water utility and photosynthetic activity of rice (Agarie et al., 1992, 1998), it also

\footnotetext{
1 Department of Horticulture, National Chung Hsing University, Taichung 40227, Taiwan, ROC.

Institute of Tropical Agriculture, Kyushu University, Fukuoka 812-8581, Japan

3 Department of Horticultural Science, National Chiayi University, Chiayi 60004, Taiwan, ROC.

* Corresponding author (E-mail: rsolin@dragon.nchu.edu.tw)
}

changed morphological and density of stomata in maize (Gao et al., 2006), increased chlorophyll and iron content, decreased proline content in cowpea (Mail and Aery, 2009), appeared thicker flower stalk, bigger diameter and blooming earlier affected leaf macro and micro element content in gerbera (Kamenidou et al., 2010), previous research indicated silicon also enhanced stresses tolerance such as increased cell wall polysaccharide content, decreased leakage at drought and heat stresses in rice (Agarie et al., 1998). Moreover, silicon applied increased superoxide dismutase, root $\mathrm{H}^{+}-$ ATPase activity, decreased lipid peroxidation and malondialdehyde content at salt stress in barley (Liang, 1999; Liang et al., 2003, 2006). Silicon could alleviate cell damage in norway spruce during aluminum stress (Prabagar et al., 2011).

Cell membrane structure, integrity and stability are most important of plant during heat stress, because it caused lipid liquefaction and electrolytes leakage of cell membrane (Ke, 2006; Yao et al., 2000). Cell membrane thermostability (CMT) has been becoming an efficiency method for evaluating heat tolerance in plants. The method measured as ion leakage from leaves over a range of temperature, it is rapid, inexpensive, requirement little space and highly correlation (Marcum, 1998; Chen et al., 2014; Yang and Hu, 2015; Yeh and Lin, 2003).

Nobile Dendrobium is belong Dendrobium nobile type and it has been found from native habitats of Himalayas, Thailand, Laos and South China (Kamemoto et al., 1999). Kuo (2011) indicated that high temperature has an influenced on development of nobile Dendrobium. In aspect of micro-propagation and breeding among Doritaenopsis and Phalaenopsis had difficultly problem to solve (Chuang et al., 2014; Liao et al., 2015), similarly to nobile Dendrobium orchid usually do not get used to higher temperature during vegetative growth around June to September (Wu, 2016). 
Therefore, it should be a limited factor during summer growing season in Taiwan. The purpose of this studies were determined cell membrane stability by CMT technique and silicon dioxide supply on development of nobile Dendrobium

\section{MATERIALS AND METHODS}

\section{Plant materials}

Dedrobium Lucky Girl plants were purchased in Mar. 2014 from an orchid nursery in Douliu, Taiwan. Those plants were brought up serval pseudobulb with 10-17 nodes and grown in 9-cm diameter soft black plastic pot in greenhouse of National Chung Hsing University horticultural research station. The light intensity was $185-216 \mu \mathrm{mol} \cdot \mathrm{m}^{-2} \cdot \mathrm{s}^{-1}$ and average temperature about $23.6-25.3^{\circ} \mathrm{C}$ of experimental locations. The plants with two pseudobulb and vegetative buds were transplanted that switched old sphagnum moss medium, then pruned part of root and reporting with new sphagnum moss in 13-cm diameter pots. Those plants were watered as needed with tap water and no fertilizer applied for control. The plants were selected for experiment in Jan. 2015.

\section{Experiment processes}

On Mar. to Oct. 2015, the plants were supplied $2 \mathrm{~g}$ per pot of Hi-Control No.1 $\left(14 \mathrm{~N}-11 \mathrm{P}_{2} \mathrm{O}_{5}-13 \mathrm{~K}_{2} \mathrm{O}, 180\right.$ type, JCAM Inc., Japan), while the pseudobulb terminal leaf had already formed and matured after that measured leaves cell membrane thermostability. In terms of silicon dioxide experiment, the plants were supplied nutrient solution (16.0 g. $\mathrm{L}^{-1} \mathrm{NH}_{4} \mathrm{NO}_{3}, 11.5 \mathrm{~g} \cdot \mathrm{L}^{-1} \mathrm{NH}_{4} \mathrm{H}_{2} \mathrm{PO}_{4}$, $48.6 \mathrm{~g} \cdot \mathrm{L}^{-1} \mathrm{MgSO}_{4} \cdot 7 \mathrm{H}_{2} \mathrm{O}, 47.2 \mathrm{~g} \cdot \mathrm{L}^{-1} \mathrm{Ca}\left(\mathrm{NO}_{3}\right)_{2} \cdot 4 \mathrm{H}_{2} \mathrm{O}, 60.6 \mathrm{~g} \cdot \mathrm{L}^{-1}$ $\mathrm{KNO}_{3}, 81.4 \mathrm{~g} \cdot \mathrm{L}^{-1} \quad \mathrm{CaCl}_{2} \cdot 2 \mathrm{H}_{2} \mathrm{O}, 47.8 \mathrm{~g} \cdot \mathrm{L}^{-1} \quad \mathrm{P}_{2} \mathrm{O}_{5}, 2.86 \mathrm{~g} \cdot \mathrm{L}^{-1}$ $\mathrm{H}_{3} \mathrm{BO}_{3}, \quad 0.22 \mathrm{~g} \cdot \mathrm{L}^{-1} \quad \mathrm{ZnSO}_{4} \cdot 7 \mathrm{H}_{2} \mathrm{O}, \quad 0.08 \mathrm{~g} \cdot \mathrm{L}^{-1} \quad \mathrm{CuSO}_{4} \cdot 5 \mathrm{H}_{2} \mathrm{O}$, $\left.1.54 \mathrm{~g} \cdot \mathrm{L}^{-1} \mathrm{MnSO}_{4} \cdot \mathrm{H}_{2} \mathrm{O}, 0.017 \mathrm{~g} \cdot \mathrm{L}^{-1} \mathrm{H}_{2} \mathrm{MoO}_{4} \cdot \mathrm{H}_{2} \mathrm{O}\right)$ with 0,75 , 150, 300 and $600 \mathrm{mg} \cdot \mathrm{L}^{-1}$ silicon dioxide (Sigma-Aldrich, USA), $200 \mathrm{~mL}$ per pot twice a weeks. Furthermore, we mentioned the leaves chlorophyll SPAD value during vegetative stage, when pseudobulb terminal leaf has already formed and matured after that measured leaves ion leakage, chlorophyll content, root activity and malondialdehyde concentration. The horticultural characteristics were also investigated.

\section{Leaves cell membrane thermostability}

The leaves for analysis were harvested from the 3-5 nodes (the location downstream from terminal leaf), and were evaluated for CMT (Cell membrane thermostability) following procedures described by Yeh and Lin (2003) with some modification. Each samples for assay consisted of five leaf discs (6 mm diameter), has rinsed three times thoroughly tap water and distilled water before assay. Leaf discs were placed in $25 \mathrm{~mL}$ flask containing $10 \mathrm{~mL}$ distilled water then was measured at 25 , $30,35,40,45,50,55,60,65$, and $70^{\circ} \mathrm{C}$ water bath temperature for $30 \mathrm{~min}$, after that the solution was measured with conductivity meter (Isfet, IQ-180, USA). The flask were capped with foil autoclaved (HY-300SV, $121^{\circ} \mathrm{C}, 1.05 \mathrm{~kg} \cdot \mathrm{cm}^{-2}$, Taiwan) for $20 \mathrm{~min}$. The calibrated relative injury (RI) was calculated as follows:

$R I(\%)=\left\{1-\left[1-\left(\mathrm{T}_{\mathrm{I}} / \mathrm{T}_{\mathrm{F}}\right)\right] /\left[1-\left(\mathrm{C}_{\mathrm{I}} / \mathrm{C}_{\mathrm{F}}\right)\right]\right\} \times 100$, where $\mathrm{T}$ and $\mathrm{C}$ refer to conductance value for treatment and control, respectively, and subscript I and F refer to initial and final conductance value, respectively.

\section{Leaves ion leakage}

The leaves for analysis were harvested from the 3-5 nodes (the location downstream from terminal leaf), and were evaluated for ion leakage following procedures described by Martineau et al. (1979) with some modification. Each samples for assay consisted of five leaf discs at $6 \mathrm{~mm}$ diameter, has rinsed three times thoroughly tap water and distilled water before assay. Leaf discs were placed in $25 \mathrm{~mL}$ flask containing $10 \mathrm{~mL}$ distilled water then was measured at $50^{\circ} \mathrm{C}$ water bath temperature for $30 \mathrm{~min}$, after that the solution was measured with conductivity meter (Isfet, IQ-180, USA). The flask were capped with foil autoclaved (HY-300SV, $121^{\circ} \mathrm{C}, 1.05 \mathrm{~kg} \cdot \mathrm{cm}^{-2}$, Taiwan) for $20 \mathrm{~min}$. The calibrated ion leakage was calculated as follows:

Leakage $(\%)=\left(R_{1} / R_{2}\right) \times 100$, where $R_{1}$ and $R_{2}$ refer to conductance value for initial and final conductance value, respectively.

\section{Malondialdehyde concentration (MDA)}

MDA concentration was measured by using Heath and Packer (1968) with some modification. The sample of $0.3 \mathrm{~g}$ leaves tissue were harvested from the $3-5$ nodes (the location downstream from terminal leaf), then homogenized with sand and $1.8 \mathrm{~mL}$ TCA (trichloroacetic acid 5\%), after that was added to $10 \mathrm{~mL}$ tube and centrifuged (Kubata, KN-70, Japan) $3500 \mathrm{rpm}$ for $15 \mathrm{~min}$. A $1 \mathrm{~mL}$ supernatant solution was added to tube containing $4 \mathrm{~mL}$ of $20 \%(\mathrm{v} / \mathrm{v}) \mathrm{TCA}$ and $0.5 \%(\mathrm{v} / \mathrm{v})$ thiobarbituric acid. The sample was heated in a water bath at $95^{\circ} \mathrm{C}$ for 30 min then quickly cooled in an ice bath followed by centrifugation at $3500 \mathrm{rpm}$ for $15 \mathrm{~min}$. The absorbance of supernatant was determined with a spectrophotometer at 532-600 nm (Hitachi, U-2001, Japan). The MDA concentration was calculated as follow: MDA (nmol.g ${ }^{-1}$ ) $=($ A532-A600 nm $) \div 155$ (extinction coefficient, $\mathrm{mM}^{-1}$. $\left.\mathrm{cm}^{-1}\right) \times 5$ (reaction volume, $\left.\mathrm{mL}\right) \times 1.8$ (dilution factor) $\times 1000 \div$ sample fresh weight $(\mathrm{g})$.

\section{Chlorophyll content}

The leaves sample were harvested from the 3-5 nodes (the location downstream from terminal leaf), and were measured by using the method of Arnon et al. (1954) and Marker (1972) with some modification. Sample of $0.1 \mathrm{~g}$ leaf tissue added $10 \mathrm{~mL}$ mixture solution (acetone: methanol=80: 20) soaked in darkness overnight, then determined with a spectrophotometer (Hitachi, U-2001, Japan) at 645, 652 and $663 \mathrm{~nm}$.

\section{Chlorophyll SPAD value}

Each leaf sample has been determined on same position, and measured with Chlorophyll Meter (SPAD502, Minolta Co. Ltd., Japan) during vegetative stage. 
The results expressed as SPAD units.

\section{Root activity}

Root activity of plants was determined by using Steponkus and Lanphear, (1967) with modified. The sample of $0.01 \mathrm{~g}$ root tip added $0.6 \%$ TTC solution (triphenyl tetrazolium chloride, $0.05 \mathrm{mM} \mathrm{Na}_{2} \mathrm{HPO}_{4}$ and $\mathrm{KH}_{2} \mathrm{PO}_{4}$ buffer $\mathrm{pH}$ 7.4) then soaked in darkness over 17 hours. The sample has been rinsed distill water and added $20 \mathrm{~mL}$ alcohol (95\%) into tube, when it being heated in a water bath at $78^{\circ} \mathrm{C}$ for $20 \mathrm{~min}$ after that quickly cooled in room temperature and determined with a spectrophotometer (Hitachi, U-2001, Japan) at $480 \mathrm{~nm}$.

\section{Statistical analysis}

The data were subjected to an analysis of variance using a completely randomized design. Separation of means among treatments was used least significant difference test at $P \leqq 0.05$. Statistical analyses were used Costat 6.1 (CoHort Software, Monterey, CA, USA). SigmaPlot software 12.5 (Systat Software Inc., Chicago, CA, USA) was used to assay regression analysis. The figures and tables were made out from the data using Microsoft Excel 2010 (Microsoft Office Software,

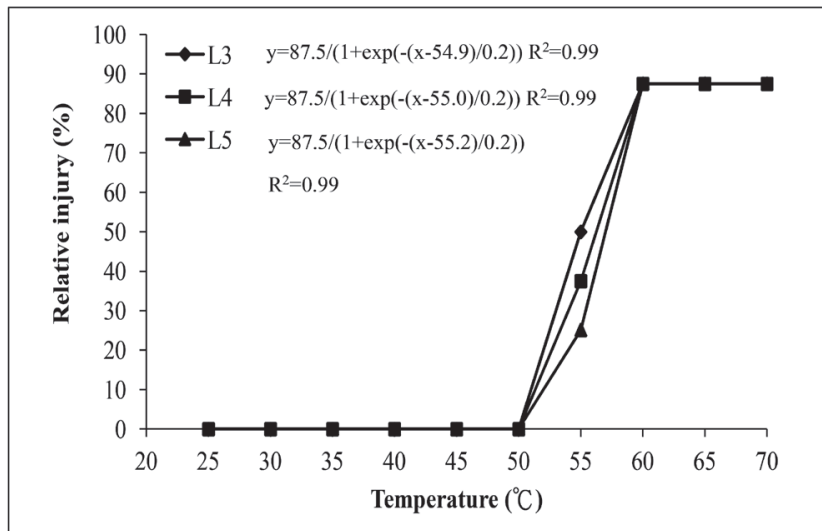

Fig. 1. Effect of water bath temperature on leaves relative injury of Dendrobium Lucky Girl. Formula represent sigmoidal regression, $\mathrm{n}=3$.

L3, L4, L5: downstream from terminal leaf 3-5 location of node

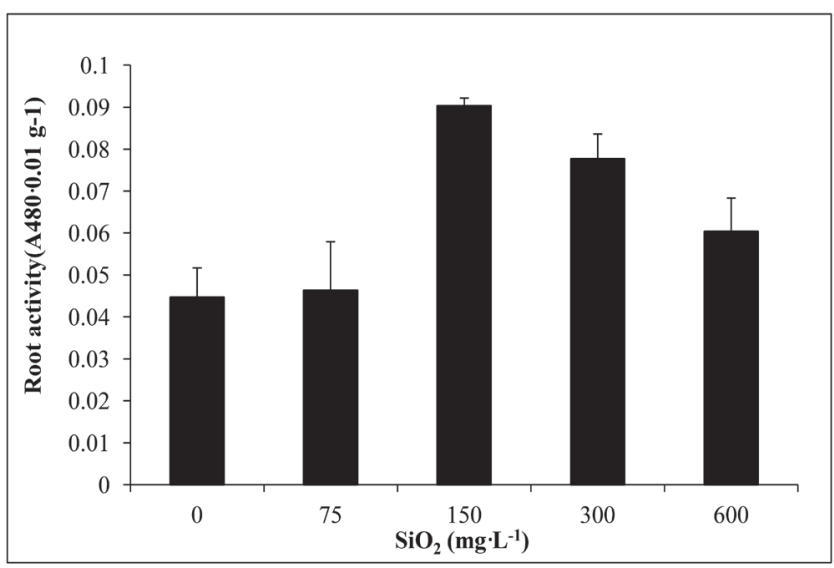

Fig. 2. Effect of silicon dioxide on root activity of Dendrobium Lucky Girl. Bar $= \pm \mathrm{SE} ; \mathrm{n}=3$.
Redmond, WA, USA).

\section{RESULTS}

The relationship between the relative injury value of leaves and water bath temperature were sigmoidal in Dedrobium Lucky Girl. The temperature has been increasing over $50.0^{\circ} \mathrm{C}$ that leaves (L3-L5) enhancing the relative injury value, the leaf (L3) appeared higher value than others (L4-5). The relative injury value midpoint of leaves position occurred the sigmoid response curve between $54.9-55.2^{\circ} \mathrm{C}$ (Fig. 1). In terms of silicon experiment, result showed higher root activity and chlorophyll SPAD value at $150 \mathrm{mg} \cdot \mathrm{L}^{-1}$ treatment (Fig. 2 and Fig. 3). The leave ion leakage emerged fluctuation when heating at $50.0^{\circ} \mathrm{C}$ for $30 \mathrm{~min}$. The leave position (L3-L5) showed lower ion leakage at $150-600 \mathrm{mg} \cdot \mathrm{L}^{-1}$ treatments compared with control (Fig. 4). Silicon dioxide treatments have gradually increasing leave chlorophyll content and decreasing MDA concentration (Table 1). In terms of horticultural characteristic, silicon dioxide treatments did not improve plant height and number of nodes, but it enhanced number of leaves during vegetative growth stage (Table 2), moreover, silicon dioxide treatments had no significant difference among numbers of flower bud, numbers of node with flower bud, flower per inflorescence and flower per pseudobulb, however $150 \mathrm{mg} \cdot \mathrm{L}^{-1}$ treatments occurred lower flower bud abortion rate during reproductive growth stage (Table 3 and Fig. 5)

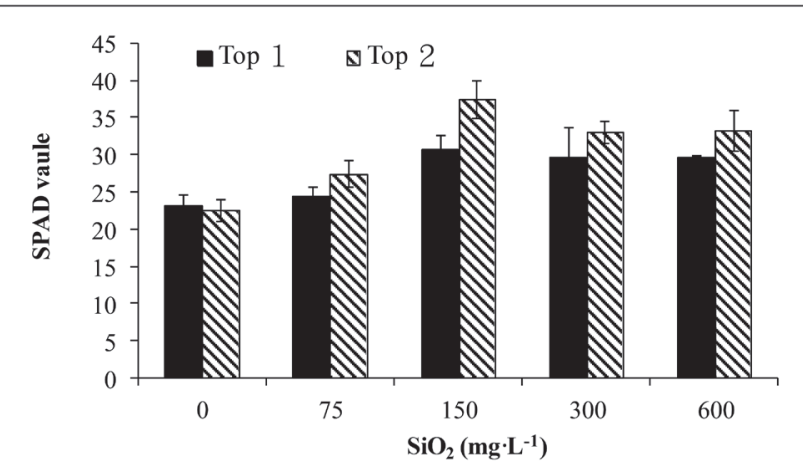

Fig. 3. Effect of silicon dioxide on SPAD value of Dendrobium Lucky Girl vegetative bud. Bar $= \pm \mathrm{SE} ; \mathrm{n}=3$.

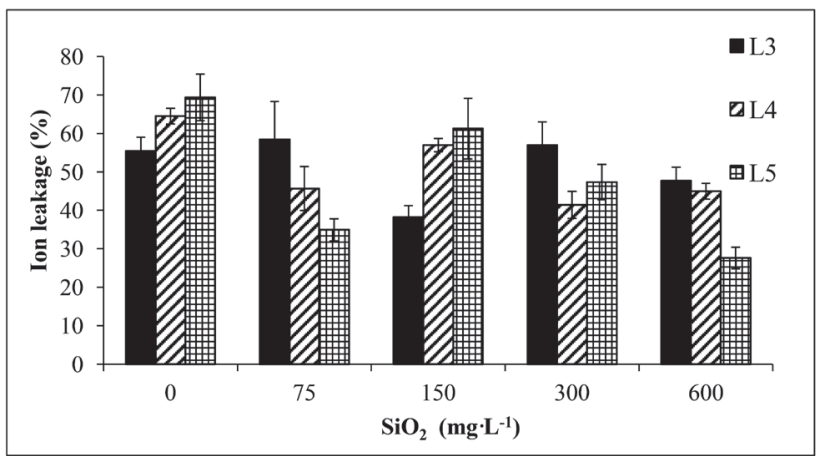

Fig. 4. Effect of silicon dioxide on leaves ion leakage of Dendrobium Lucky Girl. Bar $= \pm \mathrm{SE} ; \mathrm{n}=3$.

L3, L4, L5: downstream from terminal leaf 3-5 location of node 
Table 1. Effect of silicon dioxide on leaves malondialdehyde and chlorophyll content of Dendrobium Lucky Girl

\begin{tabular}{|c|c|c|c|c|c|c|}
\hline \multirow{2}{*}{$\begin{array}{c}\mathrm{SiO}_{2} \\
\left(\mathrm{mg} \cdot \mathrm{L}^{-1}\right)\end{array}$} & \multicolumn{2}{|c|}{$\mathrm{L}^{\mathrm{z}}$} & \multicolumn{2}{|c|}{ L4 } & \multicolumn{2}{|c|}{ L5 } \\
\hline & $\begin{array}{c}\mathrm{MDA} \\
\left(\mathrm{nmol} \cdot \mathrm{g}^{-1}\right)\end{array}$ & $\begin{array}{l}\text { Total Chl. } \\
\left(\mathrm{mg} \cdot \mathrm{g}^{-1}\right)\end{array}$ & $\begin{array}{c}\mathrm{MDA} \\
\left(\mathrm{nmol} \cdot \mathrm{g}^{-1}\right)\end{array}$ & $\begin{array}{l}\text { Total Chl. } \\
\left(\mathrm{mg} \cdot \mathrm{g}^{-1}\right)\end{array}$ & 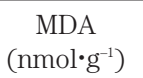 & $\begin{array}{c}\text { Total Chl. } \\
\left(\mathrm{mg} \cdot \mathrm{g}^{-1}\right)\end{array}$ \\
\hline 0 & $11.9 \mathrm{a}^{\mathrm{y}}$ & $0.54 \mathrm{c}$ & $3.5 \mathrm{a}$ & $0.62 \mathrm{c}$ & $6.0 \mathrm{a}$ & $0.61 \mathrm{~b}$ \\
\hline 75 & $4.1 \mathrm{~b}$ & $0.70 \mathrm{bc}$ & $3.4 \mathrm{ab}$ & $0.72 b c$ & $3.9 \mathrm{ab}$ & $0.65 \mathrm{~b}$ \\
\hline 150 & $3.2 \mathrm{~b}$ & $0.81 \mathrm{ab}$ & $3.6 \mathrm{ab}$ & $0.89 \mathrm{ab}$ & $2.7 \mathrm{~b}$ & $0.97 \mathrm{a}$ \\
\hline 300 & $4.2 \mathrm{~b}$ & $0.95 \mathrm{a}$ & $2.4 \mathrm{~b}$ & $0.87 \mathrm{ab}$ & $2.7 \mathrm{ab}$ & $0.87 \mathrm{ab}$ \\
\hline 600 & $1.8 \mathrm{~b}$ & $0.98 \mathrm{a}$ & $2.1 \mathrm{~b}$ & $0.98 \mathrm{a}$ & $2.8 \mathrm{~b}$ & $1.01 \mathrm{a}$ \\
\hline
\end{tabular}

${ }^{2}$ L3, L4, L5: downstream from terminal leaf 3-5 location of node

${ }^{y}$ Mean separation within each column by LSD test at $P \leqq 0.05$. n=3

Table 2. Effect of silicon dioxide on pseudobulb growth of Dendrobium Lucky Girl

\begin{tabular}{cccc}
\hline $\begin{array}{c}\mathrm{SiO}_{2} \\
\left(\mathrm{mg} \cdot \mathrm{L}^{-1}\right)\end{array}$ & $\begin{array}{c}\text { Plant height } \\
(\mathrm{cm})\end{array}$ & $\begin{array}{c}\text { Number of } \\
\text { nodes }\end{array}$ & $\begin{array}{c}\text { Number of } \\
\text { leaves }\end{array}$ \\
\hline 0 & $28.7 \mathrm{a}^{2}$ & $15.3 \mathrm{a}$ & $4.0 \mathrm{~b}$ \\
75 & $30.0 \mathrm{a}$ & $16.7 \mathrm{a}$ & $7.5 \mathrm{~b}$ \\
150 & $29.7 \mathrm{a}$ & $17.7 \mathrm{a}$ & $9.7 \mathrm{a}$ \\
300 & $28.3 \mathrm{a}$ & $16.0 \mathrm{a}$ & $10.7 \mathrm{a}$ \\
600 & $28.0 \mathrm{a}$ & $15.7 \mathrm{a}$ & $10.7 \mathrm{a}$ \\
\hline
\end{tabular}

${ }^{2}$ Mean separation within each column by LSD test at $P \leqq 0.05 . \mathrm{n}=3$.

Table 3. Effect of silicon dioxide on blooming of Dendrobium Lucky Girl

\begin{tabular}{|c|c|c|c|c|c|}
\hline $\begin{array}{c}\mathrm{SiO}_{2} \\
\left(\mathrm{mg} \cdot \mathrm{L}^{-1}\right)\end{array}$ & $\begin{array}{l}\text { Numbers of } \\
\text { flower bud }\end{array}$ & $\begin{array}{l}\text { Numbers of node } \\
\text { with flower bud }\end{array}$ & $\begin{array}{l}\text { Flowers per } \\
\text { inflorescence }\end{array}$ & $\begin{array}{l}\text { Flowers per } \\
\text { pseudobulb }\end{array}$ & $\begin{array}{c}\text { Flower bud } \\
\text { abortion } \\
(\%)^{z}\end{array}$ \\
\hline 0 & $7.7 \mathrm{a}^{\mathrm{y}}$ & $5.7 \mathrm{a}$ & $1.8 \mathrm{a}$ & $10.3 \mathrm{a}$ & $25.0 \mathrm{a}$ \\
\hline 75 & $7.3 \mathrm{a}$ & $6.3 \mathrm{a}$ & $2.0 \mathrm{a}$ & $12.3 \mathrm{a}$ & $12.5 \mathrm{ab}$ \\
\hline 150 & $8.0 \mathrm{a}$ & $7.7 \mathrm{a}$ & $2.1 \mathrm{a}$ & $15.6 \mathrm{a}$ & $2.8 \mathrm{~b}$ \\
\hline 300 & $6.3 \mathrm{a}$ & $5.0 \mathrm{a}$ & $2.1 \mathrm{a}$ & $10.0 \mathrm{a}$ & $23.1 \mathrm{a}$ \\
\hline 600 & $6.0 \mathrm{a}$ & $5.0 \mathrm{a}$ & $2.3 \mathrm{a}$ & $11.3 \mathrm{a}$ & $16.7 \mathrm{ab}$ \\
\hline
\end{tabular}

${ }^{2}$ Percentage data were logarithmic transformed prior to analysis

${ }^{y}$ Mean separation within each column by LSD test at $P \leqq 0.05 . \mathrm{n}=3$.

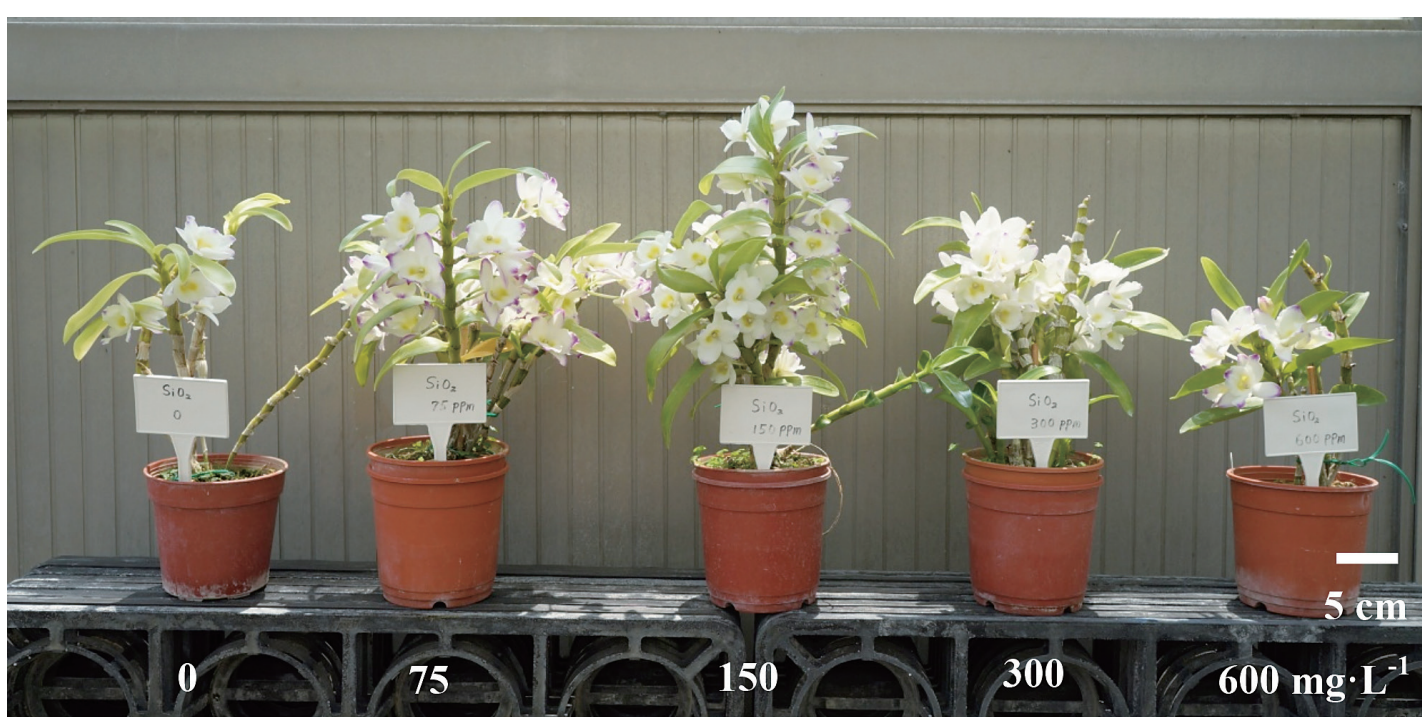

Fig. 5. Effect of silicon dioxide treatments on flowering of Dendrobium Lucky Girl. 


\section{DISCUSSION}

The cell membrane thermostability technique has been screening crop for heat tolerance in soybeans (Martineau et al., 1979), wheat (Saadalla et al., 1990), chrysanthemum (Wang and Yeh, 2013; Wang et al., 2008; Yeh and Lin, 2003), leafy radish (Chen et al., 2014), marsh-rosemary (Chang, 2014) and Phalaenopsis (Yang and $\mathrm{Hu}, 2015$ ). The exposure time and midpoint of sigmoidal curve that would able to evaluate heat tolerance of crop (Ingram and Buchanan, 1981; Lester, 1985). Result indicated the position of leaves have increasing the relative injury value after heating at $50^{\circ} \mathrm{C}$, the leaves ion leakage showed nearly midpoint among $54.9-55.2^{\circ} \mathrm{C}$, therefore cell membrane thermosstability should be able to determine at $55^{\circ} \mathrm{C}$ in Dendrobium Lucky Girl (Fig. 1). The position of leaf (L3) showed more sensitively than others leaves.

Some research indicated, silicon improved development and production of crop (Kamenidou et al., 2010; Mattson and Leatherwood, 2010; Sivanesan et al., 2010), In present experiment showed silicon dioxide treatments enhanced root activity and chlorophyll SPAD value (Fig. 2 and Fig. 3). Agarie et al. (1998) reported that silicon treatment reduced ion leakage in rice leaves, when it is heating at $42.5^{\circ} \mathrm{C}$. Ma (2004) also reported that silicon played a major role against stresses such as drought, freeze, metal ion toxin, salt, pest and disease. Result indicated that leaves (L3-5) ion leakage emerged fluctuation data, it should be discussed the assimilated difference of Den. Lucky Girl on ion leakage due to silicon dioxide concentration (Fig. 4), because silicon element absorbed, translocated and accumulated of plant by silicic acid and silica gel form, it should be consider to the ability of the roots to take up this element in monocotyledonous and dicotyledons (Epstein, 1999; Ma and Yamaji, 2006). In addition, silicon dioxide treatments increased the leaves chlorophyll content (Table 1), the result similar like Ahmad et al. (1992), Duan et al. (2013), Liang (1999) and Ma et al. (2002). Agarie et al. (1992, 1993) indicated that silicon treatments accelerated development, accumulation of dry weight and photosynthetic rate that attributed silicon maintained the chlorophyll stability. In present experiment also showed that silicon treatments decreased the malondialdehyde concentration of leaves (Table 1). Cell membrane has been received injury in adversity condition that lead to lipid peroxidation and produced the precursor is malondialdehyde (MDA), it would be able to integrate protein and enzyme in order to cause damage of cell membrane structure (Zhang and Yin, 2009; Bailly et al., 1996; Blokhina et al., 2003; Gutteridge and Halliwell, 1990; Liu and Huang, 2000b; Malencic et al., 2000). Lombardi and Wangersky (1991) reported that the marine diatom (Chaetoceros gracilis) less silicon supplement lead to break of cell membrane. Agarie et al. (1998) indicated silicon treatment prevented cell membrane function and structure damage in rice during stress environment. Wang and Galletta (1998) also reported that silicon treatment caused alternation glycolipids and phospho- lipids ratio of cell membrane. In other hand, silicon treatment also decreased lipid peroxidation and malondialdehyde content at salt stress on barley (Liang, 1999; Liang et al., 2003, 2006). Even silicon treatments did not enhance the plant height and number of node, however it has been increased number of leaves during vegetative growth stage, $150 \mathrm{mg} \cdot \mathrm{L}^{-1}$ silicon dioxide treatments appeared lower flower abortion rate (Table 2 and Table 3)

In summary, silicon element has been protected the cell membrane to stress that discussed respect to membrane integrity, stability and function of crop. Furthermore, beneficial element silicon on physiological advantage and mechanism of horticultural crop should be more investigated.

\section{AUTHOR CONTRIBUTIONS}

Shing-Kuan WU, designed this study and wrote the initial draft of the manuscript. Ikuo MIYAJIMA, offered advices on tropical horticultural crops research for efficiency experiments on heat tolerance, and revised the manuscript and inspected final data. Kuang-Liang HUANG, joined orchid research team work, designed the cultural environment for orchid research under light intensity and temperature control for studies, and offered suggestion for research. Ya-Chin KUO, worked on experimental process of fertilizer supplement and data collection. Ruey-Song LIN, organized the research protocol through physiological and biochemical experiments on heat tolerance of crops and managed lab process. The final version of this manuscript was approved by all authors.

\section{REFERENCES}

Agarie, S., W. Agata, F. Kubota and P. B. Kaufman. 1992 Physiological roles of silicon in photosynthesis and dry matter production in rice plant. I. Effect of silicon and shading treatments. Jpn. J. Crop Sci., 61: 200-206

Agarie, S., H. Uchida, W. Agata, F. Kubota and P. B. Kaufman. 1993 Effect of silicon on growth dry matter production and photosynthesis in rice plant. Crop Prod. Improve. Tech., 34: 225234

Agarie, S., H. Uchida, W. Agata, F. Kubota and P. B. Kaufman. 1998 Effect of silicon on transpiration and leaf conductance in rice plants. Plant Prod. Sci., 1: 89-95

Ahmad, R., S. H. Zaheer and S. Ismail. 1992 Role of silicon in salt tolerance of wheat (Triticum aestivum L.). Plant Sci., 85 $43-50$

Arnon, D. I., M. B. Allen and F. R. Whatley. 1954 Photosynthesis by isolated chloroplasts. Nature, 174: 394-396

Bailly, C., A. Benamar, F. Corbineau and D. Côme. 1996 Changes in malondialdehyde content and in superoxide dismutase catalase and glutathione reductase activities in sunflower seeds as related to deterioration during accelerated aging. Physiol. Plant., 97: 104-110

Blokhina, O., E. Virolainen and K. V. Fagerstedt. 2003 Antioxidants oxidative damage and oxygen deprivation stress: a review. Ann. Bot., 91: 179-194

Chaisompongpan, N., P. H. Li, D. W. David and A. H. Markhart. 1990 Photosynthetic responses to heat stress in common bean genotypes differing in heat acclimation potential. Crop Sci., 30: 100-104

Chang, Y. T. 2014 Breeding of low vernalization-requiring culti- 
vars/lines, selection indices, thermal time of flowering, and phylogenetic relationship in Limonium. $\mathrm{PhD}$ dissertation. Dept. of Hort. and Landscape Architecture. Natl. Taiwan Univ.

Chen, W. L., W. J. Yang, H. F. Lo and D. M. Yeh. 2014 Physiology anatomy and cell membrane thermostability selection of leafy radish (Raphanus sativus var. oleiformis Pers.) with different tolerance under heat stress. Sci. Hortic., 179: 367-375

Chuang, H. T., K. L. Huang, R. S. Shen, I. Miyajima and S. T. Hsu. 2014. Using cut-column pollination method overcome crossing barriers in Phalaenopsis Sunrise Goldmour 'KHM637'. J. Fac. Agr., Kyushu Univ., 59: 265-271

Duan, X. Y., M. Tang and W. S. Wang. 2013 Effect of silicon on physiology and biochemistry of Dendrobium moniliforme plantlets under cold stress. Agri. Biotechnol., 2: 18-21

Epstein, E. 1999 Silicon. Annu. Rev. Plant Physiol. Plant Mol. Biol., 50: 641-664

Gao, X. P., C. Zou, L. J. Wang and F. S. Zhang. 2006 Silicon decreases transpiration rate and conductance from stomata of maize plants. J. Plant Nutri., 29: 1637-1647

Gutteridge, J. M. C. and B. Halliwell. 1990 The measurement and mechamism of lipid peroxidation in biological systems. Trends. Biochem. Sci., 15: 129-135

Heath, R. L. and L. Packer. 1968 Photoperoxisation in isolated chloroplasts I. Kinetics and stoichiometry of fatty acid peroxidation Arch. Biochem. Biophys., 125: 189-198

Ingram, D. L. and D. Buchanan. 1981 Measurement of direct heat injury of root of three woody plant. HortScience, 16: 769-771

Kamemoto, H., T. Amore and A. R. Kuehnle. 1999 Breeding Dendrobium Orchids in Hawaii, Hawaii Univ. Press, (Honolulu), pp. 9

Kamenidou. S., T. J. Cavins and S. Marek. 2010 Silicon supplements affect floricultural quality traits and elemental nutrient concentration of greenhouse produced gerbera. Sci. Hortic., 123: $390-394$

Ke, Y. 2006 Plant Physiology, $1^{\text {st }}$ ed. Yi-Hsien Publishing Co, (Taipei), pp. 682

Kuo, W. J. 2011 Effect of environmental factors, substrates and fertilizers on growth and flowering of nobile type Dendrobium. Master's thesis. Dept. of Plant Ind. Natl. Pingtung Univ. of Sci. and Tech.

Lasseigne, F. T., S. L. Warren, F. A. Blazich and T. G. Ranney. 2007 Day/night temperature affects growth and photosynthesis of cultivated Salvia taxa. J. Amer. Soc. Hort. Sci., 132: 492500

Lester, G. E. 1985 Leaf cell membrane thermostabilities in Ccucumis melo. J. Amer. Soc. Hort. Sci., 110: 506-509

Liang, Y. C. 1999 Effect of silicon on enzyme activity and sodium potassium and calcium concentration in barley under salt stress. Plant Soil, 209: 217-224

Liang, Y. C., Q. Chen, Q. Liu, W. H. Zhang and R. X. Ding. 2003 Exogrnous silicon increase antioxidant enzyme activity and reduces lipid peroxidation in root of salt stress barley (Hordeum vulgare L.). J. Plant Physiol., 160: 1157-1164

Liang, Y. C., W. H. Zhang, Q. Chen, Y. L. Liu and R. X. Ding. 2006 Effect of exogenous silicon on H+-ATPase activity phospholipids and fluidity of plasma membrane in leaves of salt stress barley (Hordeum vulgare L.). Environ. Exp. Bot., 57: 212219

Liao, Y. W., P. L. Huang, K. L. Huang, I. Miyajima and S. T. Hsu. 2015 Factors affecting to somatic embryogenesis and plant regeneration from callus and in vitro ontogeny of Doritaenopsis Taisuco Ladylip. J. Fac. Agr., Kyushu Univ., 60: $13-22$

Liu, X. Z. and B. R. Huang. 2000a Carbohydrate accumulation in relation to heat stress tolerance in two creeping bentgrass cultivar. J. Amer. Soc. Hort. Sci., 125: 442-447

Liu, X. Z. and B. R. Huang. 2000b Heat stress injury in relation to membrane lipid peroxidation in creeping bentgrass. Crop. Sci., 40: $503-510$

Lombardi A. T. and P. J. Wangersky. 1991 Influence of phosphorus and silicon on lipid class production by the marine diatom Chaetoceros gracilis growth in turbidostat cage cultures.
Mar. Ecol. Prog. Ser., 77: 39-47

Ma, J. F. 2004 Role of silicon in enhancing the resistance of plants to biotic and abiotic stresses. Soil Sci. Plant Nutr., 50: 11-18

Ma, J. F. and N. Yamaji. 2006 Silicon uptake and accumulation in higher plants. Trends Plant Sci., 11: 392-397

Ma, C. C., Q. F. Li, L. Z. Shu and J. Y. Zhang. 2002 Preliminary exanation of the mechanism about effects of silicon on maize seed germination and seedling growth. Acta Agron. Sin., 28: 665669

Mail, M. and N. C. Aery. 2009 Effect of silicon on growth biochemical constituents and mineral nutrition of cowpea. Commun. Soil Sci. Plant Anal., 40: 1041-1052

Malencic, Dj., O. Gasic, M. Popovic and P. Boza. 2000 Screening for antioxidant properties of Salvia reflexa Hornem. Phytotherapy Res., 14: 546-548

Marcum, K. B. 1998 Cell membrane thermostability and wholeplant heat tolerance of Kentucky bluegrass. Crop Sci., $\mathbf{3 8}$ $1214-1218$

Marker, A. F. H. 1972 The use of acetone and methanol in the estimation of chlorophyll in the presence of phaeophytin. Freshwater Biol., 2: 361-385

Martineau, J. R., J. E. Specht, J. H. Williams and C. Y. Sullivan 1979 Temperature tolerance in soybeans. I. Evaluation of a technique for assessing cellular membrane therostability. Crop Sci., 19: 75-78

Mattson, N. S. and W. R. Leatherwood. 2010 Potassium silicate drenches increase leaf silicon content and affect morphological traits of serval floriculture crop grown in a peat-based substrate. HortScience, 45: 43-47

Miao, C., R. Q. Li and J. B. Wang. 1994 Ultrastructural study in leaf cell of Brassica oleracea var. capitata under heat stress. Acta Bot. Sin., 36: 730-732

Prabagar, S., M. J. Hodson and D. E. Evans. 2011 Silicon amelioration of aluminium toxicity and cell death in suspension cultures of Norway spruce (Picea abies (L.) Karst.). Environ. Exp. Bot., 70: 266-276

Saadalla, M. M., J. F. Shanahan and J. S. Quick. 1990 Heat tolerance in winter wheat: I. Hardening and genetic effects on membrane thermostability. Crop Sci., 30: 1243-1247

Sivanesan, I., M. S. Son, J. P. Lee and B. R. Jeong. 2010 Effects of silicon on growth of Tagetes patula L. Boy orange and Yellow boy seedlings cultured in an environment controlled chamber. Propag. Ornam. Plants, 10: 136-140

Steponkus, P. L. and F. O. Lanphear. 1967 Refinment of triphenyltetrazolium chloride method of determining cold injury. Plant Physiol., 42: 1423-1426

Wahid, A., S. Gelani, M. Ashraf and M. R. Foolad. 2007 Heat tolerance in plants: An overview. Environ. Exp. Bot., 61: 199-223

Wang, C. H. and D. M. Yeh. 2013 Assessment of cell Membrane thermostability of chrysanthemum and its application to screening for heat-tolerant seedlings. J. Taiwan Soc. Hort. Sci., 59: 153-166

Wang, S. Y. and G. J. Galletta. 1998 Foliar application of potassium silicate induces metabolic changes in strawberry plants. $J$. Plant Nutr., 21: 157-167

Wang, B. L., M. Xu, Q. H. Shi and J. S. Cao. 2004 Effect of high temperature stress on antioxidant systems, chlorophyll and chlorophyll fluorescence parameters in early cauliflower leaves. Sci. Agr. Sin., 37: 1245-1250

Wang, C. H., D. M. Yeh and C. S. Sheu. 2008 Heat tolerance and flowering-heat- delay sensitivity in relation to cell membrane thermostability in chrysanthemum. J. Amer. Soc. Hort. Sci. 133: $754-759$

Wu, S. K. 2016 Effect of essential nutritional elements, plant growth regulators on growth and flowering, and simulated transportation in Nobile Dendrobium. PhD dissertation. Dept. of Hort. Natl. Chung Hsing Univ.

Wu, G. S., Y. J. Wang, W. H. Cao, Y. W. Jiang and L. R. Zhang. 1995 Studies on mode of high temperature injury and screening method for heat tolerant Chinese cabbage. Acta Agr. Boreall Sin., 10: 111-115

Yang, Y. and W. C. Hu. 2015 Study on heat tolerance index of 
Phalaenopsis. Tainan District Agricultural Research and Extension Station Research Bull., 65: 1-9

Yao, Y. G., X. H. Shi, J. G. Yang and S. Y. Wang. 2000 Relation of the permeability of plasma membrane of leaves and the contents of several biochemical matter to heat tolerance of pepper. J. Hunan Agr. Univ., 26: 97-99

Yeh, D. M. and H. F. Lin. 2003 Thermostability of cell membranes as a measure of heat tolerance and relationship to flowering delay in chrysanthemum. J. Amer. Soc. Hort. Sci., 128: 656-
660

Yoshida, S. 1975 The physiology of silicon in rice. Asian and Pacific Council Food and Fertilizer Technology Center Technical Bull., 25: 1-27

Zhang, Y. F. and B. Yin. 2009 Influences of salt and alkali mixed stresses on antioxidative activity and MDA content of Medicago sativa at seedling stage. Acta Prataculturae Sin. 18: $46-50$ 